\title{
MODULAR POULTRY FARMING IN INDUSTRIAL BREEDING WITH USING AN ENERGY EFFICIENT HEATING SYSTEM
}

\author{
N. A. Spodyniuk \\ National University of Life and Environmental Sciences of Ukraine, Ukraine. \\ Correspondence of the authors: n_spoduniuk@meta.ua \\ Article history: Received: March 2019. Received in the revised form: April 2019. Accepted: June 2019. \\ Bibl. 11, fig. 3, tabl. 2.
}

\begin{abstract}
Energy-efficient heating systems for poultry houses are infrared heating systems. With the correct location of infrared emitters heating occurs only in the zone where the poultry is located and the need to heat the entire poultry house disappears. In this way, it is possible to achieve the necessary zoo-hygienic parameters in the zone for breeding of young chicken, without increasing indoor temperature, and if it is possible, lowering it. On the basis of principle of sectional poultry breeding the modular breeding of chicken broilers is proposed. The heating system of the module is a panel infrared heater, intended for local heating of the growing zone. To ensure a constant inflow of fresh air and assimilation of harmfulness in the module provides an inflow and exhaust ventilation system.
\end{abstract}

Modular poultry breeding allows to use modules as well as in industrial poultry farming, and within individual farms. As the industrial method of poultry breeding involves the accumulation of a large amount of poultry in one poultry house, there is a possibility of emergence and rapid spread of infectious diseases. Due to the local microclimate provided in the module for poultry breeding, it is possible to prevent this negative phenomenon. In addition, there is an opportunity to keep multi-year poultry categories in one poultry house and to provide a temperature regime as the growth of poultry.

In this paper the study of temperature regime in the module at the change of thermal power of a heater was described. The results of experiment show that the greatest influence on the value of relative air temperature have thermal power of infrared heater and air velocity in module. At constant values of height of a heater installation and air velocity, and with increasing the heat capacity of heater twice, value of relative air temperature will increase by $3.8 \%$.

Due to the use of energy-efficient infrared heating system, it was possible to reduce annual expenses related to the purchasing feed by $11.7 \%$ and increase cost of final product of chicken-broiler by $12.8 \%$.

Based on technical and economic calculations, the use of modular poultry breeding with the infrared heating system was substantiated. This confirms the wide possibilities of implementation energy-efficient infrared heating systems.
Key words: energy-efficient, infrared heating system, air heating system, module for poultry breeding, thermal power, poultry.

\section{Formulation of problem}

To maintain high productivity and conservation of poultry in modern industrial farming parameters of the optimal microclimate indoor poultry complexes are very important. The main factor of climate, which influences on chicken, is the ambient temperature. With the change of air temperature, consumption poultry feed, water, moisture allocation, respiratory rate also change and, consequently, change its performance.

According to the literature $[1,2]$ at low temperature in poultry houses, increased consumption of feed by poultry for implementation of heat transfer processes. With decreasing air temperature in the premises for broilers from $20^{\circ} \mathrm{C}$ to $10^{\circ} \mathrm{C}$ their growth at the age of $5 \ldots$ 8 weeks decreases by $48 \%$ that in the calculation for every temperature degree is about $6 \%$. With increasing the temperature from 24 to $32^{\circ} \mathrm{C}$ their growth reduced to $26 \%$ or by $2.9 \%$ for every temperature degree. When the air temperature is $27 \ldots 29^{\circ} \mathrm{C}$ the heat release is increased and there is an overheat of the organism, which has negative affect on the physiological state of the bird.

The main purpose of heating systems of poultry houses is to maintain the required temperature parameters in the areas of technological process of poultry breeding.

For breeding of young chicken it is advisable to provide a limited area by installing local heating systems. Temperature in heating zone should be $33-35^{\circ} \mathrm{C}$. In the process of broilers` growing to 30 days parameters of air temperature in the heating zone should decrease by $3-5^{\circ} \mathrm{C}$ every week [3].

At the age of chickens from 31 to 60 days, they are placed in cages of the poultry premises. The air temperature in broiler houses is $20^{\circ} \mathrm{C}$ at ambient temperature below $10^{\circ} \mathrm{C}[2,3]$.

\section{Analysis of recent research results}

Energy-efficient heating systems for poultry houses are infrared heating systems. With the correct location of 
infrared emitters heating occurs only in the zone where the poultry is located and the need to heat the entire poultry house disappears. In this way, it is possible to achieve the necessary zoo-hygienic parameters in the zone for breeding of young chicken, without increasing indoor temperature, and if it is possible, lowering it.

From the sanitary-hygienic point of view, infrared radiation has a positive effect on the physiological state of the poultry, especially on young chicken. The principle of infrared radiation is to transfer heat energy in the form of electromagnetic waves. Long-wavelength infrared radiation, with a wavelength of more than 1.4 microns, is almost all absorbed by the skin, causing the thermal effect of the upper layers of the skin. Short-wavelength radiation with a wavelength from 0.76 to 1.4 microns penetrates into the deeper layers of body tissues [4].

As a result of appearance of a thermal effect in the body, infrared emitters have become widely used for the heating of young poultry in the cold season of the year. In the long-term stay of poultry under the infrared heater, biological processes in the body are accelerated, metabolism is improved, tone of the autonomic nervous system is normalized, and conservation, growth and productivity of poultry are increased.

Chicken broilers are less mobile than other chicken, so badly oriented in searching of food. In the first weeks of growth poultry it is important to create such conditions that it moves less, as a result of gaining weight. For this purpose, sectional retention of poultry in the form of barriers is used, reducing the area of movement of chicken. An electric lamp with infrared emitters is used as a heating system for local heating of growing zone [5]. Limited area of the section and the dynamic regulation of thermal regime as the poultry grow contribute to a significant accumulation of weight of chickens at lower specific feed costs per unit of products.

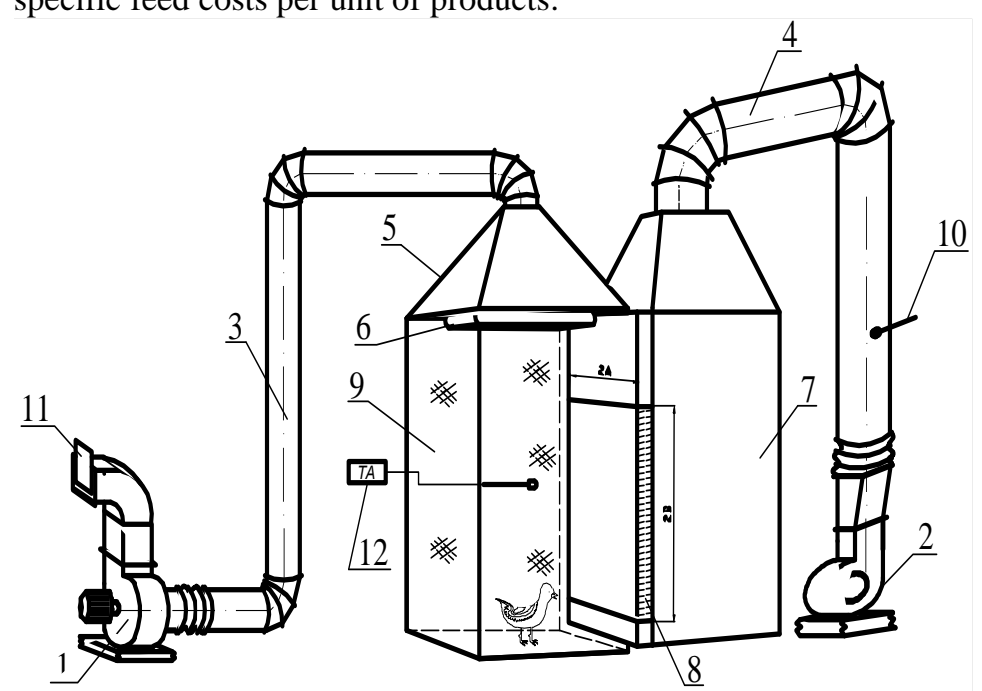

\section{Purpose of research}

On the basis of principle of sectional poultry breeding the modular breeding of chicken broilers is proposed. The heating system of the module is a panel infrared heater, intended for local heating of the growing zone. To ensure a constant inflow of fresh air and assimilation of harmfulness in the module provides an inflow and exhaust ventilation system.

Modular poultry breeding has several advantages. First of all, it is an opportunity of using modules as well as in industrial poultry farming, and within individual farms. As the industrial method of poultry breeding involves the accumulation of a large amount of poultry in one poultry house, there is a possibility of emergence and rapid spread of infectious diseases. Due to the local microclimate provided in the module for poultry breeding, it is possible to prevent this negative phenomenon. In addition, there is an opportunity to keep multi-year poultry categories in one poultry house and to provide a temperature regime as the growth of poultry.

The purpose of this publication is to develop module for poultry breeding with an infrared heater and conduct research concerning temperature regime in the module at the change of thermal power of a heater. Also the purpose was to investigate the impact of improving the microclimate parameters in module on increasing weight gain of the poultry and reducing the feed costs.

\section{Research results}

On the basis of certain rational parameters of module for poultry breeding an experimental installation was installed in full size (Fig. 1).
Fig. 1. Diagram (a)

Fig. 1. Diagram (a)

and photo (b) of experimental installation for studying parameters of thermal regime in technological area of module for poultry breeding: 1 - exhaust fan; 2 - air supply fan; 3 - exhaust air duct; 4 - supply air duct; 5 - exhaust outlet; 6 - infrared heater QH 1500; 7 - static pressure chamber; 8 - air distributor; 9 - module for poultry breeding; 10, 11 - gate; 12 - thermo-anemometer ATT - 100 .

The installation works as follows. Electric infrared heater 6 QH 1500 with variable thermal capacity of 500, 1000 and $1500 \mathrm{~W}$ was appointed for heating module for poultry breeding 9 [6, 7]. An exhaust outlet 5 was installed above the heater, with total dimensions of $0.9 \times 6.6 \mathrm{~m}$. Exhaust fan 1 was connected to the exhaust outlet 5 by the exhaust air duct 3 . Amount of air that was removed by exhaust outlet was changed by gate 11 . Air

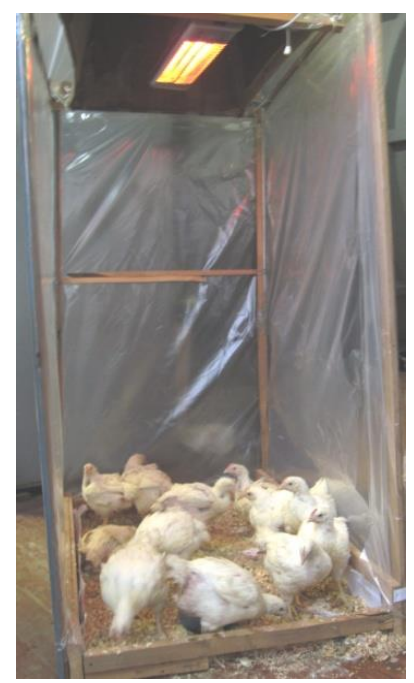

(b) 
supply fan 2 is connected to the static pressure chamber 7 using supply air duct 4. Air supply consumption was changed by the gate 10 . Inflow air was supplied to the module through the air distributor 8. Temperature and air velocity in module for poultry breeding were measured by a thermo-anemometer 12 ATT-1004.

Research was carried out at the change of height of heater installation $(1.5 \mathrm{~m}-1.0 \mathrm{~m})$ and at various heat capacities $(500 \mathrm{~W}, 1000 \mathrm{~W}, 1500 \mathrm{~W})$.

The temperature of internal air in the module for poultry breeding is influenced by heat capacity of infrared heater $Q_{\text {heat }}, \mathrm{W}$, height of the heater $H, \mathrm{~m}$, and air velocity of inflow air flow in the module $V_{0}, \mathrm{~m} / \mathrm{s}$ [8]. These values were the input parameters of the experiment planning.
Output parameter is the relative air temperature in the module for poultry breeding $\overline{t_{\text {air }}}=t_{\text {air }} / t_{0} ; t_{\text {air }}-$ air temperature in the module, ${ }^{\circ} \mathrm{C} ; t_{0}$ - temperature of the inflow air flow, ${ }^{\circ} \mathrm{C}[8]$.

The scope of definition of input parameters varied within: $Q_{\text {heat }}=[500 \ldots 1500] \mathrm{W} ; H=[1.0 \ldots 1.5] \mathrm{m}$; $V_{0}=[0.1 \ldots 0.3] \mathrm{m} / \mathrm{s}$.

Presented graphic results show a qualitative picture of distribution of temperature fields in the radiation zone by infrared heater. For scientific substantiation of air temperature dependence on the above-mentioned factors, the nomogram was built (Fig. 2).



Fig. 2. Dependence of relative air temperature $\bar{t}_{\text {air }}=t_{\text {air }} / t_{0}$ on the heat capacity of heater $Q_{\text {heat }}$, W, height of its installation $H, \mathrm{~m}$ and velocity of the inflow air flow in the module $V_{0}, \mathrm{~m} / \mathrm{s}$

At the received intervals of variation for input factors on the basis of constructed nomogram an empirical dependence was obtained for finding the relative air temperature $\bar{t}_{\text {air }}$ in the module for poultry breeding at 500 $\mathrm{W} \leq Q_{\text {heat }} \leq 1500 \mathrm{~W}, 1.0 \mathrm{~m} \leq H \leq 1.5 \mathrm{~m}, 0.1 \mathrm{~m} / \mathrm{s}$ $\leq V_{0} \leq 0.3 \mathrm{~m} / \mathrm{s}$.

$$
\begin{aligned}
& \bar{t}_{\text {air }}=1.41+0.07 \frac{Q_{\text {heat }}-1000}{500}-0.045 \frac{H-1.25}{0.25}-0.075 \frac{V_{0}-0.2}{0.1}- \\
& -0.02 \frac{Q_{\text {heat }}-1000}{500} \cdot \frac{V_{0}-0.2}{0.1}+0.0125 \frac{H-1.25}{0.25} \cdot \frac{V_{o}-0.2}{0.1}
\end{aligned}
$$

The results of experiment show that the greatest influence on the value of relative air temperature have thermal power of infrared heater and air velocity in module. At constant values of height of heater installation and air velocity, and with increasing the heat capacity of heater twice, value of relative air temperature will increase by $3.8 \%$.

The main technical and economic indicators which determine the efficiency of using modular breading of poultry with infrared heating is to reduce costs of food purchasing and an increase the weight gain of the poultry due to the high quality of heating system in the zone of poultry breeding. The calculations are presented for air heating system of poultry house in cage breading of poultry and infrared heating system of modular breading of poultry. The calculations are presented with prices for products in Ukraine in Euro.

Costs for food purchasing at air heating system with breading poultry in cages were:

$$
E_{c}^{1}=C_{c} \cdot n \cdot j \cdot z \cdot 10^{-3}, € / \text { year, }
$$

where $C_{\mathrm{c}}$ - the cost of feed for feed units in Ukraine, $€ / \mathrm{t}$; $n$ - the number of poultry units.; $j$ - daily feed 
consumption per $1 \mathrm{~kg}$ of live poultry weight is $2.1 \mathrm{~kg}$ [9]; $z$ - length of period, days.

The cost of food purchasing for the proposed application of modular breeding of poultry with infrared heating system, were determined:

$$
E_{c}^{2}=C_{c} \cdot n \cdot j \cdot z \cdot\left(1-\frac{k_{2}}{100}\right) \cdot 10^{-3}, € / \text { year, }
$$

where $k_{2}-$ coefficient of reduction of feed costs for poultry, is $3.9-5.1 \%$ [9].

Calculations were performed taking into account the increase in the weight of poultry as it grows during growth process from 1 to 60 days. Results of calculations the costs of food purchasing for comparable versions of systems are presented in the table (Table 1).

Table 1. Comparing the costs of purchasing feed for different heating systems.

\begin{tabular}{|c|c|c|c|c|}
\hline $\begin{array}{l}\text { Age } \\
\text { poultry, } \\
\text { days }\end{array}$ & $\begin{array}{l}\text { Live } \\
\text { weight, } \\
\mathrm{kg}\end{array}$ & $\begin{array}{l}\text { Feed } \\
\text { efficiency } \\
\mathrm{kg} / \mathrm{kg} \\
\text { live } \\
\text { weight }\end{array}$ & $\begin{array}{l}\text { Air } \\
\text { heating } \\
\text { system, } \\
\text { thousand } \\
€ / \text { year }\end{array}$ & $\begin{array}{l}\text { Infrared } \\
\text { heating } \\
\text { system, } \\
\text { thousand } \\
€ / \text { year }\end{array}$ \\
\hline $\begin{array}{lr}1 & \ldots . . \\
10 \text { days }\end{array}$ & 0.08 & 0.152 & 0.47 & 0.46 \\
\hline $\begin{array}{l}11 \quad \ldots . \\
30 \text { days }\end{array}$ & 0.25 & 0.475 & 3.0 & 2.61 \\
\hline $\begin{array}{l}31 \quad \ldots . \\
60 \text { days }\end{array}$ & 1.4 & 2.66 & 25.8 & 22.8 \\
\hline \multicolumn{3}{|c|}{$\begin{array}{l}\text { Total costs of technological } \\
\text { period, } \sum_{i=1}^{150} E_{\kappa} \text { thousand } € / \\
\text { period }\end{array}$} & 29.3 & 25.9 \\
\hline \multicolumn{3}{|c|}{$\begin{array}{l}\text { Total expenses for the year, } \\
\sum_{i=1}^{365} E_{\kappa} \text { thousand } € / \text { year }\end{array}$} & 117.2 & 103.5 \\
\hline
\end{tabular}

Figure 3 shows the graphical dependence of costs of purchasing feed during whole process of growing poultry from 1 to 60 days.

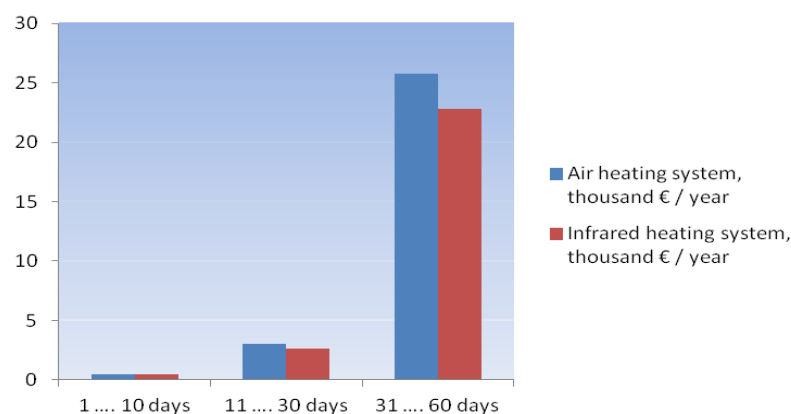

Fig. 3. Graph of the cost of purchasing feeds throughout the process of poultry production.

Then was made a comparison of the costs of final product for comparable variants. Cost of final product to air heating system with breading poultry in cages determined by the formula:

$$
E_{p r}^{1}=C_{p r} \cdot n \cdot l \cdot k \cdot z, € / \text { year, }
$$

where: $C_{\mathrm{pr}}$ - average price per unit of product in Ukraine, $€ / \mathrm{kg} ; l$ - average daily increment of the broiler, $\mathrm{kg} ; k$ average annual number of poultry in the room is 0.9 [10].

Cost of final product for the proposed modular breading of poultry with infrared heating system was determined:

$$
E_{p r}^{2}=C_{p r} \cdot n \cdot l \cdot k \cdot z \cdot\left(1+\frac{i}{100}\right) \cdot k_{\text {more }}, € / \text { year, (6) }
$$

where: $i$ - annual percentage increase in poultry productivity thanks to the improvement of the microclimate through the energy efficiency of the heating and ventilation system, is assumed to be equal to $20 \%$ [11]; $k_{\text {more }}$ - the coefficient reflecting the additionally stored livestock of the poultry in the room is equal to 1.05 [9].

The results of calculation the cost of final product by weight gain for comparative variants are summarized in the table (Table 2). Increase of mass of poultry per day, depending on the duration of technological process was considered.

\begin{tabular}{|c|c|c|c|c|}
\hline $\begin{array}{l}\text { Age } \\
\text { poultry, } \\
\text { days }\end{array}$ & $\begin{array}{l}\text { Live } \\
\text { weight, } \\
\text { kg }\end{array}$ & $\begin{array}{l}\text { Broiler } \\
\text { daily } \\
\text { gain, } \\
\mathrm{kg} / \text { day }\end{array}$ & $\begin{array}{l}\text { Air } \\
\text { heatin } \\
\mathrm{g} \\
\text { syste } \\
\mathrm{m}, \\
\text { thous } \\
\text { and } € \\
\text { / year }\end{array}$ & $\begin{array}{l}\text { Infrared } \\
\text { heating } \\
\text { system, } \\
\text { thousand } \\
€ / \text { year }\end{array}$ \\
\hline $\begin{array}{lll}1 \ldots & 10 \\
\text { days } & \\
\end{array}$ & 0.08 & 80.33 & 2.22 & 2.3 \\
\hline $\begin{array}{l}11 \ldots 30 \\
\text { days }\end{array}$ & 0.25 & 251.02 & 6.44 & 7.43 \\
\hline $\begin{array}{lll}31 \ldots & 60 \\
\text { days } & \\
\end{array}$ & 1.4 & 1406 & 36.1 & 41.6 \\
\hline \multicolumn{3}{|c|}{$\begin{array}{l}\text { Total costs of technological } \\
\text { period, } € / \text { period }\end{array}$} & 44.8 & 51.4 \\
\hline \multicolumn{3}{|c|}{ The total cost per year, $€ /$ year } & $\begin{array}{l}179.0 \\
6\end{array}$ & 205.4 \\
\hline
\end{tabular}

Table 2. Calculation the cost of final product by weight gain for different heating systems.

The table shows that the total cost of final product when using an energy efficient heating system based on an infrared heater with an exhaust umbrella will increase by 26.34 thousand Euro.

\section{Conclusions}

1. The design of module for poultry breeding with an infrared heater has been developed. The proposed design is energy-efficient and recommended for installation in poultry houses.

2. A study of temperature regime in the module at the change of thermal power of a heater was carried out. The results of experiment show that the greatest influence on the value of relative air temperature have thermal power of infrared heater and air velocity in module. At constant values of height of a heater installation and air 
velocity, and with increasing the heat capacity of heater twice, value of relative air temperature will increase by $3.8 \%$.

3. Due to the use of energy-efficient infrared heating system, it was possible to reduce annual expenses related to the purchasing feed by $11.7 \%$ and increase cost of final product of chicken-broiler by $12.8 \%$.

4. Based on technical and economic calculations, the use of modular poultry breeding with the infrared heating system was substantiated. This confirms the wide possibilities of implementation energy-efficient infrared heating systems.

\section{References}

1. Onegov A. P., Dydyriev Yu. I., Habibulov M. A. (1975). Handbook of Hygiene of Farm Animals. Rosselkhozizdat. Moscow.

2. Zakharov A. A. (1980). Application of heat in agriculture. Kolos. Moscow.

3. $D B N$ V.2.2-1-95. (1995). Buildings and structures for livestock breeding. State Committee on Construction. Kyiv.

4. Zhelykh V., Ulewicz M., Spodyniuk N., Shapoval S., Shepitchak V. (2016). Analysis of the Processes of Heat Exchange on Infrared Heater Surface. Diagnostyka. Vol. 17, No 3. 81-85.

5. Yurkevich Yu., Spodyniuk N. (2015). Energysaving infrared heating systems in industrial premises. Budownictwo o zoptymalizowanym potencjale energetycznym. Częstochowa. Poland. Vol. 16. 140-144.

6. Shepitchak V., Savchenko O., Spodyniuk N., Zhelykh V. (2015). The study of temperature fields in exposure zone of the rotary infrared heaters. Budownictwo $o$ zoptymalizowanym potencjale energetycznym, Częstochowa. Poland. Vol. 15. 178-181.

7. Shcherbovskyk S., Spodyniuk N., Stefanovych T., Zhelykh V., Shepitchak V. (2016). Development of a reliability model to analyse the causes of a poultry module failure. Eastern-European Journal of Enterprise Technologies. Vol. 4. No 3(82). 4-9. DOI: https://doi.org/10.15587/1729-4061.2016.73354.

8. Spodyniuk N., Zhelykh V., Dzeryn O. (2018). Combined Heating Systems of Premises For Breeding of Young Pigs And Poultry. FME Transactions. Vol. 46. 651-657. DOI: 10.5937/fmet1804651S.

9. Toledo R. S., Rostagno H. S., Albino L. F. T., Dionizio M. A., Carvalho D. C. de O., Nogueira E. T. (2011). Lysine nutritional requirements of broilers reared in clean and dirty environments during the pre-starter and starter phases. Revista Brasileira de Zootecnia. Vol. 40, No. $10 . \quad 2205-2210$ DOI: $10.1590 / \mathrm{s} 1516-$ 35982011001000021 .

10. Kapalo P., Spodyniuk N. (2018). Effect of the variable air volume on energy consumption - case study. IOP Conference Series Materials Science and Engineering 415. (012027). Poland. 1-7. DOI: 10.1088/1757-899X/415/1/012027.

11. Brown K. J., Farrelly R., O’Shaughnessy S. M., Robinson A. J. (2016). Energy efficiency of electrical infrared heating elements. Applied Energy. Vol. 162. 581588. DOI: 10.1016/j.apenergy.2015.10.064.

\section{Список літератури}

1. Onegov A. P., Dydyriev Yu. I., Habibulov M. A. Handbook of Hygiene of Farm Animals. Rosselkhozizdat. Moscow. 1975.

2.Zakharov A. A. Application of heat in agriculture. Kolos. Moscow. 1980.

3.DBN V.2.2-1-95. Buildings and structures for livestock breeding. State Committee on Construction. Kyiv. 1995.

4.Zhelykh V., Ulewicz M., Spodyniuk N., Shapoval S., Shepitchak V. Analysis of the Processes of Heat Exchange on Infrared Heater Surface. Diagnostyka. Vol. 17, No 3. 2016. P. $81-85$.

5.Yurkevich Yu., Spodyniuk N. Energy-saving infrared heating systems in industrial premises. Budownictwo o zoptymalizowanym potencjale energetycznym. Częstochowa. Poland. 2015. Vol. 16. P. 140-144.

6. Shepitchak V., Savchenko O., Spodyniuk N., Zhelykh $V$. The study of temperature fields in exposure zone of the rotary infrared heaters. Budownictwo o zoptymalizowanym potencjale energetycznym, Częstochowa. Poland. 2015. Vol. 15. P. 178-181.

7. Shcherbovskykh S., Spodyniuk N., Stefanovych T., Zhelykh V., Shepitchak $V$. Development of a reliability model to analyse the causes of a poultry module failure. Eastern-European Journal of Enterprise Technologies. $\begin{array}{llllll}V o l & 4 & \text { No 3(82). 2016. P. } & \text { 4. }\end{array}$ DOI: https://doi.org/10.15587/1729-4061.2016.73354.

8.Spodyniuk N., Zhelykh V., Dzeryn O. Combined Heating Systems of Premises For Breeding of Young Pigs And Poultry. FME Transactions. 2018. Vol. 46. P. 651657. DOI: $10.5937 / \mathrm{fmet} 1804651 \mathrm{~S}$.

9.Toledo R. S., Rostagno H. S., Albino L. F. T., Dionizio M. A., Carvalho D. C. de O., Nogueira E. T. Lysine nutritional requirements of broilers reared in clean and dirty environments during the pre-starter and starter phases. Revista Brasileira de Zootecnia. Vol. 40, No.10. 2011. P. 2205-2210. DOI: $10.1590 / \mathrm{s} 1516-$ 35982011001000021.

10. Kapalo P., Spodyniuk N. Effect of the variable air volume on energy consumption - case study. IOP Conference Series Materials Science and Engineering 415. (012027). Poland. 2018. P. 1-7. DOI: 10.1088/1757899X/415/1/012027.

11. Brown K. J., Farrelly R., O'Shaughnessy S. M., Robinson A.J. Energy efficiency of electrical infrared heating elements. Applied Energy. Vol. 162. 2016. P. 581-588. DOI: 10.1016/j.apenergy.2015.10.064.

\section{МОДУЛЬНЕ ВИРОЩУВАННЯ ПТИЦІ В ПРОМИСЛОВИХ УМОВАХ \\ З ВИКОРИСТАННЯМ ЕНЕРГОЕФЕКТИВНИХ СИСТЕМ ОПАЛЕННЯ \\ H. А. Сподинюк}

Анотація. Енергоефективними системами опалення для пташників $є$ інфрачервоні системи опалення. При правильному розташуванні інфрачервоних випромінювачів нагрівання відбувається лише в тій зоні, де розташована птиця, при цьому зникає необхідність обігрівати весь пташник. Таким чином можна 
досягти необхідних зоогігієнічних параметрів у зоні для розведення молодняка птиці, не підвищуючи температуру в приміщенні, а по можливості, знижуючи іiі. На основі принципу секційного розведення птиці запропоновано модульне розведення курчатбройлерів. Система опалення модуля - це панельний інфрачервоний обігрівач, призначений для локального обігріву зони для вирощування птиці. Для забезпечення постійного припливу свіжого повітря та асиміляції шкідливості в модулі передбачена система припливно-витяжної вентиляції.

Модульне вирощування птиці дозволяє використовувати модулі, як у промисловому птахівництві, так і в межах окремих господарств. Оскільки промисловий метод розведення птиці передбачає накопичення великої кількості птиці в одному пташнику, існує можливість виникнення та швидкого поширення інфекційних захворювань. Завдяки локальному мікроклімату, передбаченому в модулі вирощування птиці, можна запобігти цьому негативному явищу. Крім того, є можливість утримувати різновікові групи птиці в одному пташнику та забезпечувати температурний режим по мірі зростання птиці.

У цій роботі було описано дослідження температурного режиму в модулі при зміні теплової потужності нагрівача. Результати експерименту показують, що найбільший вплив на значення відносної температури повітря мають теплова потужність інфрачервоного нагрівача та швидкість повітря в модулі. При постійних значеннях висоти встановлення нагрівача та швидкості руху повітря та при збільшенні теплоємності нагрівача в два рази значення відносної температури повітря зросте на 3,8\%.

Завдяки використанню енергоефективної системи інфрачервоного опалення вдалося зменшити щорічні витрати, пов'язані із закупівлею кормів, на $11,7 \%$ та збільшити вартість кінцевого продукту кучати-бройлера на $12,8 \%$.

На основі техніко-економічних розрахунків обгрунтовано використання модульного вирощування птиці 3 системою інфрачервоного опалення. Це підтверджує широкі можливості впровадження енергоефективних інфрачервоних систем опалення.

Ключові слова: енергоефективна система інфрачервоного опалення, система повітряного опалення, модуль для вирощування птиці, теплова енергія, птиця.

\section{МОДУЛЬНОЕ ВЫРАЩИВАНИЕ ПТИЦЫ В ПРОМЫШЛЕННЫХ УСЛОВИЯХ С ИСПОЛЬЗОВАНИЕМ ЭНЕРГОЕФЕКТИВНИХ СИСТЕМ ОТОПЛЕНИЯ \\ Н. А. Сподинюк}

Аннотация. Энергоэффективными системами отопления птичников являются инфракрасные системы отопления. При правильном расположении инфракрасных излучателей нагрев происходит только в той зоне, где находится птица, при этом исчезает необходимость обогревать весь птичник. Таким образом можно достичь необходимых зоогигиенических параметров в зоне для разведения молодняка птицы, не повышая температуру в помещении, а по возмож- ности, снижая ее. На основе принципа секционного разведения птицы предложено модульное разведения цыплят-бройлеров. Система отопления модуля - это панельный инфракрасный обогреватель, предназначенный для локального обогрева зоны для выращивания птицы. Для обеспечения постоянного притока свежего воздуха и ассимиляции вредностей в модуле предусмотрена система приточно-вытяжной вентиляции.

Модульное выращивания птицы позволяет использовать модули, как в промышленном птицеводстве, так и в пределах отдельных хозяйств. Поскольку промышленный метод разведения птицы предполагает накопление большого количества птицы в одном птичнике, существует возможность возникновения и быстрого распространения инфекционных заболеваний. Благодаря локальному микроклимату, предусмотренном в модуле выращивания птицы, можно предотвратить это негативное явление. Кроме того, есть возможность содержать разновозрастные группы птицы в одном птичнике и обеспечивать температурный режим по мере роста птицы.

В этой работе было описано исследования температурного режима в модуле при изменении тепловой мощности нагревателя. Результаты эксперимента показывают, что наибольшее влияние на значение относительной температуры воздуха имеют тепловая мощность излучателя и скорость воздуха в модуле. При постоянных значениях высоты установки нагревателя и скорости движения воздуха и при увеличении теплоемкости нагревателя в два раза значение относительной температуры воздуха вырастет на $3,8 \%$.

Благодаря использованию энергоэффективной системы инфракрасного отопления удалось уменьшить ежегодные расходы, связанные с закупкой кормов, на $11,7 \%$ и увеличить стоимость конечного продукта цыпляты-бройлера на 12,8\%.

На основе технико-экономических расчетов обосновано использование модульного выращивания птицы с системой инфракрасного отопления. Это подтверждает широкие возможности внедрения энергоэффективных инфракрасных систем отопления.

Ключевые слова: энергоэффективная система инфракрасного отопления, система воздушного отопления, модуль для выращивания птицы, тепловая энергия, птица.

\section{Н. А. Сподинюк ORCID 0000-0002-2865-9320.}

